\title{
COL7A1 Gene Mutation
}

National Cancer Institute

\section{Source}

National Cancer Institute. COL7A1 Gene Mutation. NCI Thesaurus. Code C162448.

A change in the nucleotide sequence of the COL7A1 gene. 